\title{
Floristic analysis of Marmoucha's plant diversity (Middle Atlas, Morocco)
}

\author{
Fatima Nassif \& Abbès Tanji (*)
}

\begin{abstract}
Nassif, F. \& Tanji, A. Floristic analysis of Marmoucha's plant diversity (Middle Atlas, Morocco). Lazaroa 34: $117-140$ (2013).

As part of an ethnobotanical exploration among the Berbers of Marmoucha in the Middle Atlas in Morocco, a floristic analysis was conducted to inventory the existing plants and assess the extent of plant diversity in this area. Located in the eastern part of the Middle Atlas, the Marmoucha is characterized by the presence of various ecosystems ranging from oak and juniper forests to high altitude steppes typical from cold areas with thorny plants. The fieldwork was conducted over five years (2008-2012) using surveys and informal techniques. The results show that the number of species recorded in Marmoucha is 508 distributed over 83 families and 325 genera, representing 13\%, 54\% and 33\% of species, families and genera at the national level, respectively. With 92 species, the Asteraceae is the richest family, representing $18 \%$ of the total reported followed by Poaceae and the Fabaceae. From a comparative perspective, the ranking of the eight richer families of the local flora in relation to their position in the national flora reveals a significant match between the positions at local and national levels with slight ranking differences except in the case of Rosaceae. In the study area, the number of endemics is significant. It amounts to 43 species and subspecies belonging to 14 families with the Asteraceae counting 10 endemics. The numbers of Moroccan-Algerian and strictly Moroccan endemics compared to other categories of endemics are rather significant. The study area host to 37 species and subspecies distributed in 16 families that could be considered rare or endangered, being Asteraceae the richest with 9. We considered Marmoucha an area with a high diversity with an important contigent of endemic, rare, and endangered species. Available information on these species is scarce. Therefore, it is imperative to pay further attention to them for conservation purposes, in order to elaborate the red list in Morocco.
\end{abstract}

Keywords: Morocco, Middle Atlas, Marmoucha, species richness, endemism, rare species.

Abstract: Nassif, F. \& Tanji, A. Análisis florístico de la diversidad vegetal de Marmoucha (Atlas Medio, Marruecos). Lazaroa 34: 117-140 (2013).

Como parte de una investigación etnobotánica entre los bereberes de Marmoucha, en el Medio Atlas en Marruecos, se realizó un estudio florístico para poder evaluar la magnitud de la biodiversidad de plantas de dicha área. Situado en la parte oriental del Atlas Medio, Marmoucha se caracteriza por la presencia de diversos ecosistemas que van desde bosques de robles y enebros a estepas típicas de las zonas frías de alta montaña que, además, llevan plantas espinosas. El trabajo de campo se llevó a cabo durante cinco años (2008-2012) mediante encuestas. Los resultados muestran que el número de especies registradas en Marmoucha es 508 distribuidas en 83 familias y 325 géneros, que representan el 13\%, 54\% y 33\% de las especies, familias y géneros a nivel nacional, respectivamente. Con 92 especies, Asteraceae es la familia más rica, lo que representa el 18\% del total registrado en la flora local Marmoucha. En segundo y tercer lugar, las dos familias más ricas son Poaceae y Fabaceae, respectivamente. Desde una perspectiva comparativa, el ranking de las ocho familias más ricas de la flora local en relación con su posición en la flora nacional revela una coincidencia significativa entre las posiciones a nivel local y nacional, con ligeras diferencias de clasificación, salvo en el caso de Rosaceae. En el área de estudio, el número de especies endémicas es significativo, asciende a 43 especies y subespecies pertenecientes a 14 familias con 10 especies endémicas de Asteraceae. Los porcentajes de Marruecos y Argelia, así como las especies endémicas de Maruecos son bastante significativos en comparación con otras categorías. El número de especies y subespecies consideradas raras o en peligro de extinción alcanza las treinta y siete, distribuidas en 16 familias. Al igual que en el cómputo total Asteraceae cuenta con el mayor número de especies (9). Consideramos que la región de Marmoucha se caracteriza por una gran diversidad, pero escasamente estudiado, por lo tanto, parece necesario aumentar los esfuerzos de cara a su conservación.

Palabras clave: Marruecos, Atlas Medio, Marmoucha, riqueza florística, endemismo, especies raras.

\footnotetext{
* National Institute for Agronomic Research. CRRA-Settat, Morocco. E-mail: fatima.nassif@gmail.com
} 


\section{INTRODUCTION}

Like many countries of the world, Morocco's mountains are centers of plant-diversity and endemism. Studies confirm that mountains are undoubtedly a reservoir of biodiversity and that the main areas for endemism in Morocco are located in the Rif and Atlas mountains, especially at high altitudes and peaks (Fennane 1987; Benabid \& Fennane, 1994; Fennane, 2004; Fougrach \& al., 2007). Mountains are also considered favorable environments for rare plants.

Located in the mountainous part of the Boulemane province, the Marmoucha region exemplifies the typical physical and bioclimatic characteristics of the structural entity generally referred to as the Folded Middle Atlas. These include altitudes of more than $1500 \mathrm{~m}$ and a subhumid Mediterranean climate with very cold winters. The region is also characterized by the presence of quite diverse ecosystems including oak, cedar and juniper forests, alfa steppes and high altitudes pastures where xerophytes predominate.

While working with goat farmers in the Ait Bazza community (NASSIF \& El AMIRI, 2011), it was necessary to study pasture plants. As we were trying to learn about prevailing ecosystems and plants, we become fascinated by the plant diversity in such a limited territorial area. Conducting bibliographical research to increase our understanding of the study area, we were surprised by the lack of information at all levels. In the process, our concerns with issues of mountain biodiversity conservation, documentation, and preservation of local knowledge systems led us to start an ethnobotanical exploration in 2008. Since then, fieldwork was intensified and the territorial basis of Aït Bazza was extended to include the neighboring communities making up the Marmoucha area. Most importantly, one of the objectives was to identify the plants present in the Marmoucha territory and to assess the plant diversity in that area. This paper presents the floristic analysis of plants collected in Marmoucha.

\section{MATERIALS AND METHODS}

Several methods and research techniques have been used. They include questionnaire surveys, working with key informants, and transects across the Marmoucha territory. Since 2008, several fieldwork activities of varying duration were conducted in the study area. The last fieldwork took place during May of 2012. The main goal was to generate significant primary data. Most important techniques used with relevance to this paper are:

- A survey of 70 goat farmers at Aït Bazza. Although the survey questionnaire focused on goat production, there were questions on pasture ecosystems and vegetation.

- A series of interviews to men and women, which are from the four rural communities of Marmoucha.

- A series of direct observations on the basis of pre-determined transects across the study area (forests, steppes, mountains, along the oueds, near the springs) to ensure adequate coverage of relatively different ecosystems. Unidentified plants were collected for subsequent identification.

In addition, several personal communications were conducted with researchers and academics from various national and international institutions working on plants.

The botanical nomenclature adopted is based on the most relevant documents on Morocco's flora in order to find and verify plant names and their synonyms and to avoid controversial sources of information. Frequently used references are the five volumes of the synonymic index of North Africa plants (DobignARD \& CHATElAin, 20102013) and the two volumes of the vascular flora of Morocco (Fennane \& IBN Tattou, 2005; IBN TATTOU \& FEnNANE, 2009). Additional references include the two volumes of "Flore Pratique du Maroc" (Fennane \& al., 1999-2007) and the 16 volumes of the "Flore de l'Afrique du Nord" (MAIRE, 1952-1987).

\section{RESULTS AND DISCUSSION}

\section{LOCATION AND MAIN CHARACTERISTICS OF THE STUDY AREA}

Administratively, the Marmoucha area refers to the territorial entity covering the municipality of Imouzzer Marmoucha and the following four 
rural communes: Aït Bazza, Aït Elmane, Almis Marmoucha, and Talzemt. This entity is part of the Cercle of Boulemane, Boulemane province.

Geographically, the study area is located in the structural entity indicated in the literature as the Folded Middle Atlas. Boutayeb stated that this part of the Middle Atlas consists of five rows of plain synclines separated from each other by four anticlinal axes. The whole entity is fashioned in limestone and marno-limestone, mainly jurassic series (BOUTAYEB, 1996).

Located in a highly mountainous area, the Marmoucha territory is not uniform in terms of altitude. In fact, altitude levels vary between $1400 \mathrm{~m}$ to over $3000 \mathrm{~m}$. The municipality of Imouzzer Marmoucha, which is the urban center of the region, is located at $1650 \mathrm{~m}$ (PeYRe, 1976; RAHOU, 1996). High altitudes cover most of the study area. More precisely, with the exception of Almis Marmoucha where the altitude amounts to $1600 \mathrm{~m}$ and the mountainous terrain covers $60 \%$ of the commune, mountain topography covers between $75 \%$ and $86 \%$ for Talzemt and Ait Bazza. The rest of the territory consists of basins and valleys near the oueds.

The study area is entirely subject to a Mediterranean climate. It has different bioclimatic and vegetation stages. The main bioclimates are:

- Mesomediterranean (1400 to $1800 \mathrm{~m}$ )

- Supramediterranean (1800 to $2200 \mathrm{~m}$ )

- Montanomediterranean (2200 to $2700 \mathrm{~m}$ )

Precise climate data on different altitudinal gradients in the area are rare or they do not exist. On average, annual rainfall varies from less than $200 \mathrm{~mm}$ in the east to $800 \mathrm{~mm}$ in the west (BouTAYEB, 1996). Based on the meteorological station at Imouzzer Marmoucha, PeYre (1976) gives an average of $438 \mathrm{~mm}$. To explain the low value of rainfall despite the altitude, Peyre wrote, "Despite its altitude and its apparent position in the wind, the station of Imouzzer Marmoucha is not watered because it is partially protected by Tichoukt (2400-2700 m), which blocks much of what remains of moist air masses that have crossed the mountains dominating Azrou and Ifrane" (PEYRE, 1976). Two decades later, RAHOU (1996) reported for Imouzzer Marmoucha an average annual rainfall of $450.9 \mathrm{~mm}$ during the period of 1933-1955. The exact amounts of snow are not known, but it is noted that the mountain peaks receive snow between November and May.

With respect to soils, BERKAT AND TAZI (2006) report that brown soils and rendzinas are dominant in the Middle Atlas with lithosols and regosols on steep slopes. As part of the folded part of the Middle Atlas, the study area is characterized by the predominance of clay and limestone soils (BOUTAYEB, 1996), followed by loam and sandy soils. The study area is also characterized by a great diversity of natural ecosystems including green oak and cedar forests, alfa steppes, and high altitude pasture ecosystems.

\section{DIVERSITY OF MARMOUCHA'S FLORA}

First, it must be pointed out that the inventory of plant species established in the Marmoucha area is far from exhaustive, but it is very likely that the species recorded represent the majority of the local flora. The number of spontaneous and cultivated species recorded is of 508 (Appendix 1) representing 13\% of Morocco's vascular flora which counts 3913 species according to the latest statistics (FEnNANE \& IBN TAтtou, 2012). Recorded species belong to 83 families and 325 genera representing 54\% and 33\% respectively of total national families and genera.

Table 1 and Figure 2 list the families according to the number of species inventoried. Of the 83 families identified, 10 families have more than 10 species and 40 families are represented by a single species. Asteraceae is the richest family in the local flora of Marmoucha. With 92 species, this family constitutes $18 \%$ of the total reported. In second and third places, the two richest families are respectively the Poaceae and Fabaceae.

Representation and matching local flora and national flora

As indicated in Figure 1, there are eight families with more than one hundred species in Morocco's flora. With 550 species (Table 2), Asteraceae ranks first, followed by Fabaceae and Poaceae in second and third places with 424 and 355 species, respectively. The Brassicaceae, Caryophy llaceae and Lamiaceae count 212, 204 and 202 species, respectively. Occupying the 7 th and 8th ranks, Apiaceae and Scrophulariaceae count 153 and 134 species respectively. 
Table 1

Observed plant families in Marmoucha

\begin{tabular}{|c|c|c|c|}
\hline Plant family & N. species & Plant family & N. species \\
\hline Asteraceae & 92 & Verbenaceae & 2 \\
\hline Poaceae & 48 & Aceraceae & 1 \\
\hline Fabaceae & 45 & Agavaceae & 1 \\
\hline Brassicaceae & 32 & Amaryllidaceae & 1 \\
\hline Lamiaceae & 28 & Apocynaceae & 1 \\
\hline Apiaceae & 23 & Araliaceae & 1 \\
\hline Rosaceae & 21 & Arecaceae & 1 \\
\hline Amaranthaceae & 15 & Aristolochiaceae & 1 \\
\hline Caryophyllaceae & 13 & Asparagaceae & 1 \\
\hline Plantaginaceae & 11 & Berberidaceae & 1 \\
\hline Solanaceae & 10 & Buxaceae & 1 \\
\hline Boraginaceae & 7 & Cactaceae & 1 \\
\hline Cistaceae & 7 & Cannabaceae & 1 \\
\hline Polygonaceae & 7 & Caprifoliaceae & 1 \\
\hline Rubiaceae & 7 & Crassulaceae & 1 \\
\hline Ranunculaceae & 6 & Cynomoriaceae & 1 \\
\hline Cucurbitaceae & 6 & Dipsacaceae & 1 \\
\hline Papaveraceae & 6 & Ephedraceae & 1 \\
\hline Salicaceae & 6 & Equisetaceae & 1 \\
\hline Convolvulaceae (incl. Cuscutaceae) & 5 & Ericaceae & 1 \\
\hline Cupressaceae & 5 & Gentianaceae & 1 \\
\hline Malvaceae & 5 & Grossulariaceae & 1 \\
\hline Oleaceae & 5 & Heliotropaceae & 1 \\
\hline Resedaceae & 5 & Iridaceae & 1 \\
\hline Euphorbiaceae & 4 & Juglandaceae & 1 \\
\hline Primulaceae & 4 & Juncaginaceae & 1 \\
\hline Scrophulariaceae & 4 & Liliaceae & 1 \\
\hline Thymelaeaceae & 4 & Molluginaceae & 1 \\
\hline Alliaceae & 3 & Nitrariaceae & 1 \\
\hline Cyperaceae & 3 & Onagraceae & 1 \\
\hline Fagaceae & 3 & Orobanchaceae & 1 \\
\hline Geraniaceae & 3 & Portulacaceae & 1 \\
\hline Hyacinthaceae & 3 & Rhamnaceae & 1 \\
\hline Juncaceae & 3 & Rutaceae & 1 \\
\hline Moraceae & 3 & Santalaceae & 1 \\
\hline Pinaceae & 3 & Smilacaceae & 1 \\
\hline Anacardiaceae & 2 & Taxaceae & 1 \\
\hline Asphodelaceae & 2 & Typhaceae & 1 \\
\hline Campanulaceae & 2 & Urticaceae & 1 \\
\hline Lythraceae & 2 & Vitaceae & 1 \\
\hline Tamaricaceae & 2 & Zygophyllaceae & 1 \\
\hline Tuberaceae & 2 & & \\
\hline
\end{tabular}

\section{ENDEMISM IN MAROUCHA'S LOCAL FLORA}

The most comprehensive work on rare, threatened, and endemic species in Morocco is produced by Fennane and Ibn Tattou in 1998. An update is included in the two volumes of the Vas- cular Flora of Morocco (Fennane \& IBn TATtou, 2005; IBN TATTOU \& FenNane, 2009). According to the latest statistics on the current inventory of the vascular flora of Morocco, FenNANE \& IBN TATTOU (2012) indicates that the number of strict endemics amounts to 640 species, which is $16.3 \%$ 


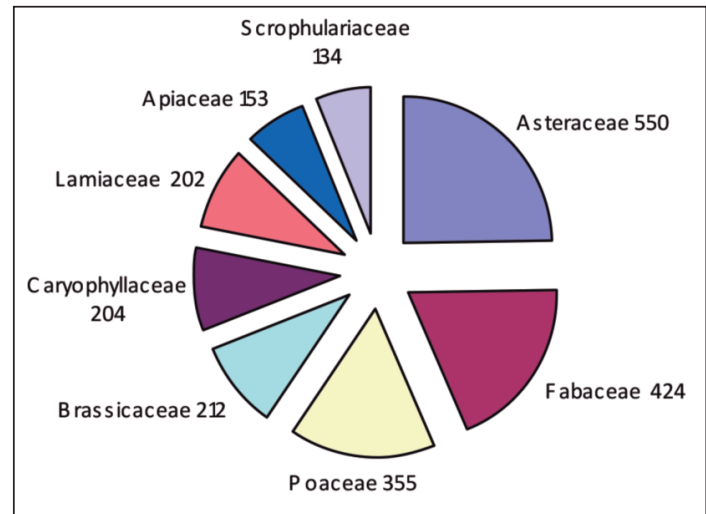

Figure 1.- The eight richest plant families in Morocco's vascular flora.

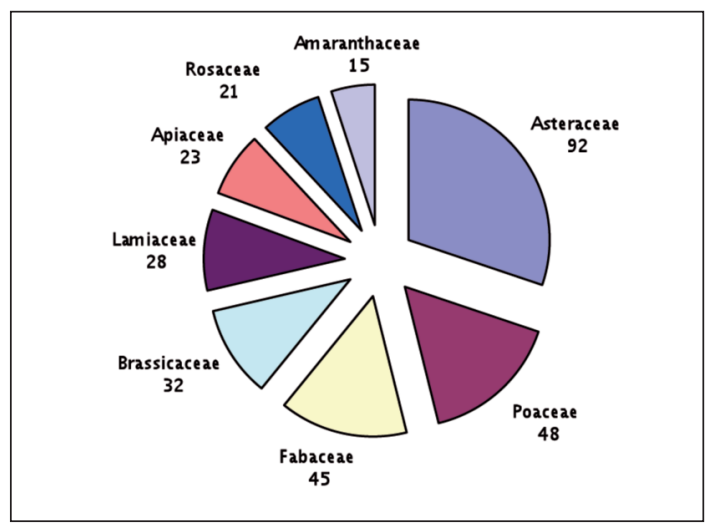

Figure 2. - The eight richest plant families in Marmoucha's local flora. of the national inventory. The number of subspecies exclusively Moroccan amounts to 280. In addition, Morocco shares an additional 607 endemic species with neighboring areas, with a clear predominance of Iberian-Moroccan endemics (210), Moroccan-Algerian (208), and Ibero-MoroccanAlgerian endemics (130). With a rate of $40 \%$, the Lamiaceae occupies the first place for the most endemics. The genus Teucrium ranks first (with $50 \%$ ) for species that are strictly Moroccan, followed by the following four genera Silene, Centaurea, Ononis, and Astragalus with rates between 22 and 33\% (FENNANE \& IBN TATTOU, 2012).

Table 3 presents the classification of the eight richest families of the local flora in relation to their position in the national flora. It indicates a clear correspondence between the positions of the richest families in the local and Moroccan flora with slight ranking differences except in the case of the Rosaceae. In other words, the Rosaceae comes in seventh position in the local flora of Marmoucha while it occupies the 13th place in the national flora. This correspondence is not surprising given the diversity of ecosystems in Marmoucha's territory, ranging from forests of cedar or oak to mountain pastures of xerophytes. The Rosaceae's visible difference can be explained by the mountainous character of the study area being extremely favorable to the growth of Rosaceae in both spontaneous and cultivated forms.

\section{Table 2}

Number of species in the Marmoucha flora compared with the distribution of the eight first plant families of the vascular flora of Morocco (families with more than one hundred species)

\begin{tabular}{lccc}
\hline Plant family & $\begin{array}{c}\text { Number of spontaneous } \\
\text { species in Morocco's } \\
\text { vascular flora (N) }\end{array}$ & $\begin{array}{c}\text { Number of spontaneous } \\
\text { and cultivated species } \\
\text { inventoried in Marmoucha's flora (n) }\end{array}$ & $\mathrm{n} / \mathrm{N}^{*} 100$ \\
\hline Asteraceae & 550 & 92 & 16.7 \\
Fabaceae & 424 & 45 & 10.6 \\
Poaceae & 355 & 48 & 13.5 \\
Brassicaceae & 212 & 32 & 15.1 \\
Caryophyllaceae & 204 & 13 & 6.4 \\
Lamiaceae & 202 & 28 & 13.9 \\
Apiaceae & 153 & 23 & 15.0 \\
Scrophulariaceae & 134 & 4 & 3.0 \\
Sub-total & 2234 & 285 & 12.8 \\
Other families & 1679 & 224 & 13.3 \\
Total & 3913 & 509 & 13.0 \\
\hline
\end{tabular}


Table 3

Ranking of the first eight richest plant families in the flora of Marmoucha compared with their rank in the national flora. For every family the number of species in the Marmoucha area (N. Marmoucha), the rank in the local flora (Local Rank) and the Rank in the National flora (Nat. Rank; number of species, n.) is detailed.

\begin{tabular}{lccc}
\hline Plant family & N. Marmoucha & Local Rank & Nat. Rank (n.) \\
\hline Asteraceae & 92 & 1 & $1(550)$ \\
Poaceae & 48 & 2 & $3(355)$ \\
Fabaceae & 45 & 3 & $2(424)$ \\
Brassicaceae & 32 & 4 & $4(212)$ \\
Lamiaceae & 28 & 5 & $6(202)$ \\
Apiaceae & 23 & 6 & $7(173)$ \\
Rosaceae & 21 & 7 & $13(62)$ \\
Amaranthaceae (incl. Chenopodiaceae) & 15 & 8 & $8(79)$ \\
\hline
\end{tabular}

In Marmoucha, the local flora is characterized by the presence of numerous strictly Moroccan, Moroccan-Algerian, or Moroccan-Iberian endemics. Table 4 provides an indicative list of these species using the following categories: E: endemic strictly of Morocco, I: endemic of Morocco and the Iberian Peninsula, A: endemic of Morocco and Algeria, IA: Ibero-Moroccan-Algerian (Fennane \& Ibn Tattou, 2012) and AT: endemic of Morocco, Algeria and Tunisia.

Based on Table 4, two important remarks seem necessary. First, the number of endemics in the study area is significant. It amounts to 43 species and subspecies belonging to 14 families. The $A s-$ teraceae count 10 endemics. Second, the numbers of Moroccan-Algerian and strictly Moroccan endemics compared to other categories of endemics are rather significant. In Morocco, endemics, especially those strictly Moroccan, are still plagued with serious shortcomings. In general, they are the least-studied and least-known species of the national flora. Based on our modest experience with bibliographic searches both in the literature and in the databases available in the Internet, it was noted that when the species was a strictly Moroccan endemic, information, photos and references become scarce. Available information is preserved in specialized institutes and centers where the species specimen is kept.

The importance and need for botanical and ethnobotanical research on strictly Moroccan endemics in particular are justified in more than one respect (HSEINI \& KAHOUADJI, 2007; HSEINI \& al., 2007; SALHI \& al., 2010). Endemics shared with neighboring countries are relatively well studied compared to exclusively Moroccan endemics. Until now, information on the latter is rare. It is paradoxical that there is a lack of information on native plants, while these plants need to be better understood to be protected, valued, and preserved, at least theoretically. Moroccan endemics deserve more attention and special efforts to know and to preserve them and, by the same token contribute to the universal knowledge of plants and biodiversity conservation.

\section{RARE AND ENDANGERED PLANTS IN MARMOUCHA}

In Morocco, the floristic diversity both nationally and locally is exposed to the pressures and threats caused primarily by direct and indirect human activities. BERRAHO \& al. (2006) report that the impact of various human activities goes against biodiversity preservation and sustainable management of natural resources. According to these authors, "in extreme cases the negative impact of these activities led to the irreparable loss of animal and plant species and irreversible damage to some ecosystems" (BERRAHO \& al., 2006).

As noted earlier, the first catalog for rare, threatened, or endemic plants in Morocco's vascular flora is that published by FENNANE and IBN TATTOU in 1998. This catalog inventories 126 families, 2185 species and 634 subspecies. Two volumes on the vascular flora of Morocco (FENNANE \& IBn TATTOU, 2005; IBN Tattou \& FenNANE, 2009) update the 1998 catalog and include 
Table 4

Marmoucha endemic plants reported in the literature.

(Endemism type: E, Morocco strictly endemic; A, Morocco-Algeria endemic;

AT, Morocco-Algeria-Tunisia endemic).

Family / species $\begin{gathered}\text { Endemism } \\ \text { type }\end{gathered}$

Apiaceae

Bupleurum atlanticum Murb.

Eryngium triquetrum Vahl subsp. xauense

(Pau) Jovet \& Sauvage

Asteraceae

Achillea leptophylla M. Bieb.

Anacyclus pyrethrum (L.) Link.

Carduus ballii Hook. f. (incl. Carduus nutans

L. subsp. subacaulis J. Arènes)

Carthamus pomelianus (Batt.) Prain

Centaurea boissieri DC.

Centaurea diluta Aiton subsp. algeriensis

(Coss.\& Durieu) Maire

Centaurea nana Desf.

Cynara baetica (Spreng.) Pau subsp.

maroccana Wiklund

Hypochaeris radicata L. subsp. platylepis

(Boiss.) Jahand. \& Maire

Leontodon saxatilis Lam. subsp. mesorhyncus

(Maire) Maire

Ptilostemon dyricola (Maire) Greuter

Berberidaceae

Berberis hispanica Boiss. \& Reuter

Boraginaceae

Echium flavum Desf.

Erysimum grandiflorum Desf.

2011

Erysimum incanum G. Kunze

2011

Rorippa africana (Br.-B1.) Maire

= Nasturtium africanum $\mathrm{Br}$.-B1.

Vella pseudocytisus L.

Caryophyllaceae

Arenaria armerina Bory

Bufonia mauritanica Murb.

Cerastium gibraltaricum Boiss.

Herniaria pujosii Sauvage \& Vindt
E Fennane \& Ibn Tattou, 1998; Fennane \& Ibn TATTOU, 2005; FENNANE \& AL., 2007; Dobignard \& Chatelain, 2011

E Fennane \& Ibn Tattou, 1998; Dobignard \& ChATELAIN, 2011

A Bellakhdar, 1997; Dobignard \& Chatelain, 2011

A Bellakhdar, 1997; Dobignard \& Chatelain, 2011

E FenNane \& IBN TATTOU, 1998; IBN TATTOU \& FENNANE, 2009; DobIGNARD \&

Chatelain, 2011

A Fennane \& Ibn Tattou, 1998; Dobignard \& Chatelain, 2011

E Fennane \& Ibn TATtou, 1998; Ibn TATTOU \& Fennane, 2009; Taleb \& Fennane, 2009;

DobignaRd \& Chatelain, 2011

A FenNane \& IBN TATTOU, 1998; Dobignard

\& Chatelain, 2011

A FenNane \& IBN TATtou, 1998; Dobignard \& Chatelain, 2011

E Fennane \& Ibn Tattou, 1998; Ibn Tattou \& FEnNANe, 2009; DobignaRd \& Chatelain, 2011

AT Fennane \& IBN TATtou, 1998; Dobignard \& Chatelain, 2011

E Fennane \& IBN Tattou, 1998; Ibn TatTou \& Fennane, 2009; Dobignard \& Chatelain, 2011

E Fennane \& Ibn TATtou, 1998; Ibn Tattou \& FenNANe, 2009; Dobignard \& Chatelain, 2011

A Bellakhdar, 1997; FenNane \& al., 1999; DobignaRd \& Chatelain, 2011

FenNane \& al., 2007; Dobignard \& Chatelain, 2011

AT FenNane \& al., 1999; Dobignard \& Chatelain,

E Fennane \& Ibn Tattou, 1998; Fennane \& IbN TATTOU, 2005; Dobignard \& ChatElain, 2011

A Fennane \& Ibn TAtTou, 1998; Fennane \& al., 1999; DoBIGNARD \& CHATELAIN, 2011

E Fennane \& al., 1999; Dobignard \& Chatelain, 2011

A FenNANe \& al., 1999; Dobignard \& Chatelain, 2011

A FENNANE \& al., 1999; DobignARD \& Chatelain, 2011

A FenNANE \& IBN TATTOU, 1998; FenNANe \& al., 1999; Dobignard \& Chatelain, 2011 
Family / species

Endemism Reference type

Fabaceae

Astragalus bourgeanus Coss.

A FenNANE \& al., 2007; VAldes \& al., 2002;

Astragalus granatensis Lam.

E $\quad$ FENNANE \& al., 2007; VALDES \& al., 2002;

Genista quadriflora Munby

A FENNANE \& al., 2007; VALDES \& al., 2002;

Hippocrepis neglecta Lassen

DOBIGNARD \& ChATELAIN, 2012

Lotus arenarius Brot.

E Fennane \& Ibn Tattou, 2005; Fennane \& al., 2007; Dobignard \& Chatelain, 2012

Ononis pseudoserotina Batt. \& Pit.

E FenNANe \& al., 2007; DobignARD \& Chatelain, 2012

E FenNane \& IBN TATTOU, 1998; FenNane \& IBN TATTOU, 2005; FENNANE \& al., 2007;

Ononis thomsonii Oliv.

E FenNANE \& IBN TATTOU, 1998; FENNANE \& IBN TATTOU, 2005; FENNANE \& al., 2007; VALDES \& al., 2002; Dobignard \& ChATELAIN, 2012

Lamiaceae

Nepeta nepetella $\mathrm{L}$.

= Nepeta amethystina Poiret

A Fennane \& Ibn Tattou, 1998; Fennane \& al., 2007; DobignARD \& Chatelain, 2012

Origanum elongatum (Bonnet) Emberger \& Maire

Teucrium chamaedrys L. subsp. gracile (Batt.)

Rech. F.

Thymus munbyanus Boiss. \& Reuter

A

A

Thymus zygis L.

A

Oleaceae

Fraxinus dimorpha Coss. \& Durieu

Pinaceae

Cedrus Atlantica (Endl.) Carrière

Plantaginaceae

Globularia nainii Batt.

Plantago mauritanica Boiss. \& Reut.

Plantago rhizoxylon Emb.

Veronica rosea Desf.

Salicaceae

Salix atrocinerea Brot.

AT

Scrophulariaceae

Scrophularia macrorrhyncha (Humbert, Litard. \& Maire) Ibn Tattou

Thymelaeaceae

Thymelaea virgata (Desf.) Endl.
FenNane \& IBN TATTOU, 2005; FenNANE \& al., 2007; VALDES \& al., 2002; DOBIGNARD \&

Chatelain, 2012

Fennane \& IBN TATTOU, 1998; DobignaRd \&

Chatelain, 2012

FENNANE \& al., 2007; VALDES \& al., 2002;

DOBIGNARD \& CHATELAIN, 2012

FEnNANE \& al., 2007; Dobignard \& Chatelain, 2012

A FenNANE \& al., 1999; VAldes \& al., 2002; FenNANE \& IBN TATTOU, 2005; Dobignard \& Chatelain, 2013

E FenNANe \& IbN TATTOU, 1998; FEnNANe \& IBn TATTOU, 2005; FENNANE \& al., 2007; Dobignard \& Chatelain, 2013

A VAldES \& al., 2002; FenNANE \& al., 2007; TALEB \& Fennane, 2008 ; Dobignard \& Chatelain, 2013

E Fennane \& Ibn Tattou, 1998; Fennane \& IBn TATtou, 2005; FenNANe \& al., 2007; Dobignard \& Chatelain, 2013

A Fennane \& Ibn Tattou, 1998; Valdes \& al., 2002; FENNANE \& IBN TATTOU, 2005; DobIGNARD \& Chatelain, 2013

VALDES \& al., 2002; FoUGRACH \& al., 2007; DOBIGNARD \& CHATELAIN, 2013

E Fennane \& IbN TATtou, 1998; Fennane \& IBN TATTOU, 2005; FENNANE \& al., 2007; DobIGNARD \& Chatelain, 2013

A Valdes \& al., 2002; Fennane \& IbN TATtou, 2005; FEnNANe \& al., 2007; Dobignard \& Chatelain, 2013 
new rare or threatened taxa. Until today, these two volumes prove to be the most comprehensive sources and most updated information on rare and endangered plants in Morocco. Thus, these references are widely used to identify reported rare and endangered plants that are inventoried in the Marmoucha local flora (Table 5). Degrees of rarity and vulnerability are those used in the cata$\log$ Fennane \& Ibn Tattou (1998), IbN Fennane \& Tattou (2005) and Ibn Tattou \& FEnNANe (2009). The six categories are:

- RR: very rare, number of known localities $\leq 5$.

- RR?: suspected very rare.

- R: rare

- R?: suspected rare

- V: vulnerable (or appears to be), could become rare in the short term.

Inventoried plants in Marmoucha considered rare or threatened comprise 37 species and subspecies belonging to 16 families. With 9 species, the Asteraceae is the family containing the most rare and endangered species, followed distantly by the remaining families.

\section{CCONSERVATION AND PROTECTION OF LOCAL PLANT DIVERSITY}

Beyond the immediate uses and services that the Marmoucha people derive from their floristic resources, the most important value of this heritage lies in plant genetic resources and its contribution to national plant diversity. For these reasons, the preservation and conservation of these resources are of outmost importance.

In other words, in the case of Aegilops for example, its highest value is not in its use as feed but in its potential use as a breeding parent and the possibility of extracting disease resistance genes or other interesting traits. In fact, many wild species are used in breeding programs. Scientists, particularly breeders and genetic resource specialists, are unanimous on the importance of wild species for plant improvement activities and the development of new varieties of cereals, fodder or food legumes. If we take the example of cereals, Aegilops, which is abundant in these mountains, is actually used in crosses of hard and soft wheat to improve their resistance to disease.
Since the United Nations Conference on Environment and Development (Earth Summit) in 1992 and the Conference of Parties to the present, the issue of biodiversity conservation has taken a new dimension. Morocco ratified the Convention in August 1995 and therefore is called to comply with the CBD and COP decisions. For example, Morocco is called to undertake activities towards the achievement of the 16 targets of the updated Global Strategy for Plant Conservation (GSPC) 2011-2020.

In his article on floristic research in Morocco, FEnNANE (2008) explicitly described the situation in Morocco in relation to the initial GSPC 20022010 . As pointed out by the author, the strategy aimed at the achievement of 16 targets by 2010 . For Morocco the task is non-achievable under prevailing conditions. The author looks at five targets as examples to support his assertion. Selected targets are the following:

- Target 1: A widely-accessible working list of known plants, as a step towards a complete world flora.

- Target 2: A preliminary assessment of the conservation status of all known plant species at national, regional and international levels.

- Target 5: Protection of 50\% of the most important areas for plant diversity assured.

- Target 7: 60\% of the world's threatened species conserved in situ.

- Target 15: The number of trained people working with appropriate facilities in plant conservation increased, according to national needs, to achieve the targets of this Strategy.

In Fennane's words, targets 1 and 15 can be achieved if there is the will, but the other three targets had no chance to be achieved by 2010 (FEnNANe, 2008). According to this author, "In fact, before conservation and protection, one must know targeted species or environments. But so far, our knowledge in these areas is imprecise, fragmentary, and non-updated" (FEnNANE, 2008). It must be pointed out that the updated GSPC 2011-2020 is more demanding and presents even greater challenges for Morocco.

Until today, Morocco's flora still experiences serious flaws. In their recent article on the latest statistics concerning Morocco' vascular flora, 
Table 5

Rare and endangered species in Marmoucha based on the literature

(For every species the following information is added: Conservation status: RR, very rare, number of known localities $\leq 5$; RR?, suspected very rare; R, rare; R?, suspected rare; V, vulnerable, or appears to)

\begin{tabular}{lll}
\hline Family / species & Cons. & LITERATURE \\
& Status & \\
\hline
\end{tabular}

Amaranthaceae

Atriplex rosea $\mathrm{L}$.

RR FEnNANE \& IBN TATTOU, 1998; FenNANE \& IBN TATTOU, 2005

Apiaceae

Bupleurum atlanticum Murb. Subsp. atlanticum Murb.

Daucus carota L. subsp. carota L.

Eryngium triquetrum Vahl subsp. xauence (Pau) Jovet \& Sauvage

Asteraceae

Carduus ballii Hook. f.

Carthamus pomelianus (Batt.) Prain

Centaurea boissieri DC. subsp. boissieri DC.

Centaurea diluta Aiton subsp. algeriensis

(Cosson \& Durieu) Maire

Centaurea nana Desf.

Hypochaeris radicata L. subsp. platylepis (Boiss.) Jahand. \& Maire

Launaea fragilis (Asso) Pau

Leontodon saxatilis Lam. subsp. mesorhynchus (Maire) Maire

Tragopogon porrifolius L. subsp. macrocephalus (Pomel) Batt.

Brassicaceae

Rorippa Africana (Braun-Blanq.) Maire

Vella mairei Humbert

Caryophyllaceae

Dianthus sylvestris Wulfen subsp. longibracteatus

(Maire) Greuter \& Burdet

Herniaria pujosii Sauvage \& Vindt

Vaccaria hispanica (Mill.) Rauschert subsp.

hispanica

Cupressaceae

Juniperus thurifera L.

Fabaceae

Astragalus caprinus L.

Ononis pseudoserotina Batt. \& Pit.

Ononis thomsonii Oliv.

Geraniaceae

Erodium malacoides (L.) L'Hér. subsp. brevirostre (Maire \& Sam.) Guitt.
$\mathrm{R}$

Fennane \& Ibn TATtou, 1998

RR FENNANE \& IBN TATTOU, 1998

R FenNane \& IBN TATtou, 1998; Fougrach et al., 2007

RR FENNANE \& IBN TATTOU, 1998

R? FENNANE \& IBN TATTOU, 1998

R FENNANE \& IBN TATTOU, 1998; IBN TATTOU \& FENNANE, 2009

RR FEnNANe \& IBN TATtou, 1998

R? FenNANE \& IBN TATTOU, 1998; IBN TATTOU \& FENNANE, 2009

RR FENNANE \& IBN TATtou, 1998

R? $\quad$ FENNANE \& IBN TATTOU, 1998

$\mathrm{R} \quad$ FENNANE \& IBN TATTOU, 1998

RR Fennane \& Ibn TATtou, 1998

R FENNANE \& IBN TATTOU, 1998

R FenNane \& IBN TATTOU, 1998; Fennane \& Ibn TatTou, 2005

R Fennane \& Ibn Tattou, 1998; Fennane \& IBN TATTOU, 2005

R? FEnNane \& IBN Tattou, 1998; Fennane \& IBN TATTOU, 2005

R? FEnNANE \& IBn TATtou, 1998; Fennane \& IBN TATTOU, 2005

V Fennane \& Ibn Tattou, 1998; Fennane \& IBN TATTOU, 2005

R FenNane \& IBN TATTOU, 1998

R FenNane \& Ibn TATTOU, 1998; Fennane \& IBN TATTOU, 2005

R Fennane \& IbN TATtou, 1998; Fennane \& IBN TATTOU, 2005

R Fennane \& Ibn Tattou, 1998; Fennane \& IbN TATTOU, 2005 
Family / species

Lamiaceae

Nepeta nepetella L. subsp. amethystina Poiret

Origanum elongatum (Bonnet) Emb. \& Maire

Teucrium chamaedrys L. subsp. gracile Batt.

Rech.f.

Liliaceae

Tulipa sylvestris $\mathrm{L}$.

Plantaginaceae

Plantago major L. subsp. intermedia (Gigib.)

Lange

Plantago rhizoxylon Emb.

Veronica rosea Desf. subsp. virgata

(Emb. \& Maire) Dobignard \& D. Jordan

Poaceae

Hordeum murinum L.

Koeleria splendens Presl.

\section{Scrophulariaceae}

Scrophularia macrorrhyncha (Humbert, Litard. \& Maire) Ibn Tattou

Solanaceae

Atropa belladonna L.

Lycium europaeum L.

Taxaceae

Taxus baccata $\mathrm{L}$.

Zygophyllaceae

Balanites aegyptiaca (L.) Delile

\section{Cons. LITERATURE}

Status

RR FENNANE \& IBN TATTOU, 1998

V FENNANE \& IbN TATTOU, 1998;

FoUgraCH et al., 2007

RR Fennane \& Ibn Tattou, 1998; Fennane \& IBN TATTOU, 2005

RR Fougrach et al., 2007

RR Fennane \& Ibn Tattou, 1998; Fennane \& IBN TATTOU, 2005

RR FENNANE \& IBN TATTOU, 1998; FENNANE \& IBN TATTOU, 2005

RR FENNANE \& IBN TATTOU, 1998

RR FEnNANe \& IBN TATTOU, 1998; FenNane \& IBN TATTOU, 2005; FougraCH et al., 2007

R Fennane \& Ibn TATtou, 1998; Fennane \& IBN TATTOU, 2005;

FOUGRACH et al., 2007

RR FENNANE \& IBN TATTOU, 1998

RR FEnNane \& IBN TATtou, 1998

R ? FENNANE \& IBN TATTOU, 1998; FENNANE \& IBN TATTOU, 2005

Fennane \& Ibn TATtou, 1998; Fougrach et al., 2007

V $\quad$ Fennane \& IBn TATTOU 1998
Fennane \& Ibn Tattou (2012) shed explicit doubts on the presence of 157 species and 28 subspecies in Morocco. Besides, according to these authors, there are numerous plant species of which distribution areas are poorly known or ill-known. To bring about solutions to all these problems, it is necessary to conduct field work. The problems are more acute in the case of rare and threatened plants. Most importantly, the authors point out that unfortunately, Morocco does not yet have an 'official' red list that meets the criteria of the International Union for Conservation of Nature (IUCN). The establishment of this list remains a priority for the country. Its consensual nature requires a real voluntary contribution of all actors, including managers and scientists (FEnNANe \& IBn TatTou, 2012).

The Marmoucha area is an example of the many local mountainous areas where plant diversity is substantial, where endemics are important and where rare and threatened species need further work. It is thus urgent to pay greater attention to the changing dynamics of local and regional flora in Morocco. Some regions are more exposed to exploitation and pressure than others. Scientists and concerned actors in diversity conservation are unanimous regarding the need and the urgency to know, protect, and preserve the national floristic heritage and its local and regional variants. 


\section{CONCLUSION}

Throughout this article, it is clear that Marmoucha's geographical, ecological, and cultural specificities are accompanied by high plant diversity. Until today, the Marmoucha people, whose main economic activity is small ruminant production, continue to draw their livelihoods from available plant resources. Because of natural as well as human factors, the fragility and vulnerability of this mountainous environment are increasing and the plant resources are at risk of degradation and erosion. Under such conditions, the people's vulnerability is also increasing. Sustainability necessitates a balance between production of goods and services, their use by the people and the preservation of the resource base unique to this environment.

To a certain extent, Marmoucha can be considered representative of other fragile, underdeveloped mountain communities with high poverty and vulnerability rates. In these situations, it would be neither wise nor fair to these areas and their people to establish large protected areas or select species for reforestation on exclusively ecological criteria without any consideration of the people's needs. The challenge is not in the choice of technical solutions and their implementation but in their reconciliation with the socioeconomic conditions of these communities and the sustainable use and management of available resources.

\section{ACKNOWLEDGMENTS}

The authors extend their special thanks to Mohamed Ibn Tattou, Abdelkader Taleb, Errol Véla, Jean Paul Peltier, and Guy-Georges Guittonneau for their assistance with the identification of some species. The authors are very grateful to anonymous reviewers and to the people of Marmoucha for their time and help with the local names.

\section{REFERENCES}

Bellakhdar, J. - 1997 - La pharmacopée marocaine traditionnelle: médecine arabe ancienne et savoir populaires — Ibis Press, Paris. 760 pp.

Benabid, A. \& Fennane, M. -1994-Connaissanees sur la végétation du Maroc: Phytogéographie, phytosociologie et séries de végétation - Lazaroa 14: 21-97.

Berkat, O. \& Tazi, M. -2006- Country pasture / forage resource profiles, Morocco - http://www.fao.org/ag/ AGP/AGPC/doc/counprof/Morocco/morocco.htm

Berraho, A., Birouk, A. \& Menioui, M. -2006- Biodiversité et équilibres écologiques - Rapports thématiques. Pp. 123-185.

Boutayeb, T. - 1996- Les potentialités de développement du Moyen-Atlas oriental et leur appréciation par les acteurs locaux - Rev. Geogr. Alp. 84(4): 51-60.

Dobignard, A. \& Chatelain, C. -2010-2013- Index synonymique flore d'Afrique du Nord. Conservatoire et Jardin Botaniques, ville de Genève, vols. 1-5.

Fennane, M. - 1987 - La Grande Encyclopédie du Maroc. Flore et Végétation, vol. 4. Pp. 8-14. G.E.M., Rabat.

Fennane, M. -2004- Propositions de zones importantes pour les plantes au Maroc (ZIP Maroc) - Atelier national «zones importantes de plantes au Maroc», Rabat.

Fennane, M. - 2008- Les recherches floristiques au Maroc: passé riche, présent difficile et avenir incertain - Prospec. Univ. Rev. Univ. Mohammed V 1: 109-116.

Fennane, M. \& Ibn Tattou, M. - 2005- Flore vasculaire du Maroc, inventaire et chorologie, vol. 1 - Inst. Sci. Univ. Mohammed V, Agdal, Rabat.
Fennane, M. \& Ibn Tattou, M. - 1998- Catalogue des plantes vasculaires rares, menacées ou endémiques du Maroc - Bocconea 8: 1-243.

Fennane, M. \& Ibn Tattou, M. - 2012 - Statistiques et commentaires sur l'inventaire actuel de la flore vasculaire du Maroc - Bull. Inst. Sci. Rabat sec. Sci. 34(1): $1-9$.

Fennane, M., Ibn Tattou, M, Ouyahya, A. \& El Oualidi, J. -2007- Flore Pratique du Maroc, volume 2. Manuel de détermination des plantes vasculaires - Trav. Inst. Sci. Sér. Bot. 38, 648 pp.

Fennane, M., Ibn Tattou, M., Mathez, J., Ouyahya, A. \& El Oualidi, J. - 1999 - Flore pratique du Maroc: Manuel de détermination des plantes vasculaires, vol. 1 - Ed. Okad. 558 pp.

Fougrach, H., Badri, W. \& Malki, M. -2007- Flore vasculaire rare et menacée du massif de Tazekka (région de Taza, Maroc). Bulletin de l'Institut Scientifique, Rabat, section Sciences de la Vie, ${ }^{\circ} 29,1-10$.

Hseini, S. \& Kahouadji, A. -2007- Étude ethnobotanique de la flore médicinale dans la région de Rabat (Maroc occidental) - Lazaroa 28: 79-92.

Hseini, S., Kahouadji, A., Lahssissene, H. \& Tijane, M. 2007 - Analyses floristique et ethnobotanique des plantes vasculaires médicinales utilisées dans la région de Rabat (Maroc occidental) - Lazaroa 28: 93-100.

Ibn Tattou, M. \& Fennane, M. -2009- Flore vasculaire du Maroc, inventaire et chorologie, vol. 2 - Inst. Sci. Univ. Mohammed V, Agdal, Rabat. 
Maire, R. -1952-1987- Flore de l'Afrique du Nord, volumes 1-16 - Ed. Lechevalier, Paris.

Nassif, F. \& El Amiri, B. -2011- Goat production systems in a mountainous community of the Middle Atlas, Morocco In: Bernués, A., Boutonnet J.P., Casasus, I., Chentouf, M., Gabiña,D., Joy, M.,López-Francos,A., Morand-Fehr, P. and Pacheco F. (Eds.). Economic, social and environmental sustainability in sheep and goat production systems. Pp. 199203. Options méditerranéennes: Série A. Séminaires Méditerranéens, $n^{\circ}$ 100. CIHEAM, FAO, CITA-DGA, Zaragoza.

Peyre, C. - 1976- Contribution à l'étude de la végétation du Moyen-Atlas oriental, le versant sud du massif du Bou Iblane et sa bordure méridionale. Eléments de climatologie - Bull. Inst. Sci. Rabat 1: 173-197.
Rahou, A. - 1996 - Aperçu sur le climat et la végétation de Bou Nacer (Moyen-Atlas oriental, Maroc) - Bull. Inst. Sci. Rabat 20 : 113-122.

Salhi, S., Fadli, M., Zidane, L. \& Douira, A. - 2010 - Etudes floristique et ethnobotanique des plantes médicinales de la ville de Kénitra (Maroc) - Lazaroa 31: 133-146.

Taleb, M.S. \& Fennane, M. - 2008- Diversité floristique du parc national du Haut Atlas Oriental et des massifs Ayachi et Maâsker (Maroc) - Acta Bot. Malacitana 33: 125-145.

Valdés, B., Rejdali, M., Achhal El Kadmiri, A., Jury, J.L. \& Montserrat, J.M. (Eds.) - 2002- Catalogue des plantes vasculaires du Nord du Maroc, incluant des clés d'identification, 2 volumes -C.S.I.C., Madrid.

Received: 27 November 2012

Accepted: 21 June 2013

\section{APPENDIX 1}

List of spontaneous and cultivated plants recorded in Marmoucha (Middle Atlas, Morocco)

For every species the following information is added: Record number (N.): if the species is cultivated $(*)$, or if the local name has not been collected (\#)

\begin{tabular}{|c|c|c|}
\hline N. & Species & Local name (s) \\
\hline & Aceraceae & \\
\hline 1 & $\begin{array}{l}\text { Acer monspessulanum } \mathrm{L} . \\
\text { Agavaceae }\end{array}$ & qiqeb \\
\hline 2 & $\begin{array}{l}\text { Agave americana } \mathrm{L} \text {. } \\
\text { Alliaceae }\end{array}$ & sabra \\
\hline $3 *$ & Allium cepa $\mathrm{L}$. & bsal \\
\hline $4^{*}$ & Allium sativum $\mathrm{L}$. & tichert \\
\hline 5 & $\begin{array}{l}\text { Allium sp. } \\
\text { Amaranthaceae (incl. Chenopodiaceae) }\end{array}$ & tichert lekhla \\
\hline 6 & Amaranthus albus $\mathrm{L}$. & blitou \\
\hline 7 & Amaranthus blitoides S. Watson & blitou \\
\hline 8 & Amaranthus retroflexus $\mathrm{L}$. & blitou \\
\hline $9 *$ & Atriplex nummularia Lindl. & armaz \\
\hline 10 & Atriplex patula $\mathrm{L}$ & tibidas \\
\hline 11 & Atriplex rosea $\mathrm{L}$ & $\#$ \\
\hline 12 & Beta macrocarpa Guss. & tibidas \\
\hline $13^{*}$ & Beta vulgaris L. & barba \\
\hline 14 & $\begin{array}{l}\text { Blitum exsuccum C. Loscos } \\
\text { (incl. Chenopodium foliosum var. minus (Vahl) Asch.) }\end{array}$ & blitou \\
\hline 15 & Chenopodium album $\mathrm{L}$. & blitou \\
\hline 16 & Chenopodium ambrosioides L. & mkhinza \\
\hline 17 & Chenopodium murale L. & blitou \\
\hline 18 & Chenopodium opulifolium Schrad. & blitou \\
\hline 19 & Chenopodium vulvaria $\mathrm{L}$. & blitou \\
\hline 20 & $\begin{array}{l}\text { Polycnemum fontanesii Durieu \& Moq. } \\
\text { Amaryllidaceae }\end{array}$ & zour lhasran \\
\hline 21 & $\begin{array}{l}\text { Narcissus sp. } \\
\text { Anacardiaceae }\end{array}$ & abehlellou \\
\hline 22 & Pistacia lentiscus L. & tidecht, fadis \\
\hline 23 & $\begin{array}{l}\text { Pistacia terebinthus } \mathrm{L} . \\
\text { Apiaceae }\end{array}$ & adil n-ouchen \\
\hline 24 & Ammi majus L. & tawsna \\
\hline
\end{tabular}


25* Apium graveolens $\mathrm{L}$.

26 Bifora testiculata (L.) Spreng.

27 Bunium fontanesii (Pers.) Maire

(incl. B. bulbocastanum auct. Afr. N.)

28 Bupleurum atlanticum Murb.

29 Bupleurum spinosum Gouan

30* Coriandrum sativum $\mathrm{L}$.

31 Daucus carota L.

32* Daucus carota var. sativa

33 Eryngium campestre L.

34 Eryngium triquetrum Vahl

35 Ferula communis L.

$36 \quad$ Foeniculum vulgare Mill.

37 Helosciadium nodiflorum (L.) W. D. J. Koch

38 Hohenackeria exscapa (Steven) Koso-Pol.

39 Orlaya platycarpos W. D. J. Koch

40* Pastinaca sativa L.

41* Petroselinum crispum (Mill.) Fuss

42 Ridolfia segetum (Guss.) Moris

43 Scandix pecten-veneris L.

44 Torilis nodosa (L.) Gaertn.

45 Turgenia latifolia (L.) Hoffm.

46 Visnaga daucoides Gaertn.

(incl. Ammi visnaga (L.) Lam.)

Apocynaceae

$47 \quad$ Nerium oleander $\mathrm{L}$.

Araliaceae

$48 \quad$ Hederahelix L.

Arecaceae (Palmae)

49 Chamaerops humilis L.

Aristolochiaceae

$50 \quad$ Aristolochia paucinervis Pomel

Asparagaceae

51 Asparagus acutifolius L.

Asphodelaceae

52 Asphodelus acaulis Desf.

53 Asphodelus ramosus L. (incl. A. microcarpus Viv.)

Asteraceae

$54 \quad$ Achillea leptophylla M. Bieb.

55 Anacyclus homogamos (Maire) Humphries

56 Anacyclus pyrethrum (L.) Link

57 Arctium atlanticum (Pomel) H. Lindb.

58* Artemisia arborescens (Vaill.) L.

59 Artemisia campestris L.

60 Artemisia herba-alba Asso

61 Atractylis caespitosa Desf.

62 Atractylis cancellata $\mathrm{L}$.

63 Bellis annua L.

64 Bombycilaena discolor (Pers.) M. Laínz

65 Calendula arvensis (Vaill.) L.

66 Carduus ballii Hook. f.

(incl. C. nutans L. subsp. subacaulis J. Arènes)

67 Carduus chevallieri Barratte krafes

qozber aghioul

aytar, achtar

tizleft

ayrbaz, aguerbaz

qozber

khizzou

khizzou

aqerchal

tlatert n-ouchen

ouffal

irden wamsa

tithjamine

\#

fetchras

tiâabouzine

maâdnous

\#

temchat

khizzou n-qnine

fetchras

bechnikha

alili

anesfal, tanesfalt

tizdemt, tizden

berrezdem

mezzr-izm

aberway

aberway

chih lekhrissi

ghadou mlal

tindazt, tawanzawiyis

mezzr-izm

chiba

izri

izri

achennoud

tiçennanine insi

\#

\#

\#

assennan

sart aghioul 
68 Carduus pycnocephalus L.

69 Carlina brachylepis (Batt.) Meusel \& Kastner (incl. C. involucrate auct. Afr. N.)

$70 \quad$ Carlina hispanica Lam.

71 Carlina macrophylla (Desf.) DC.

72 Carthamus caeruleus L.

73 Carthamus lanatus L.

74 Carthamus pinnatus Desf.

75 Carthamus pomelianus (Batt.) Prain

76 Carthamus rhaponticoides (Pomel) Greuter

$77 \quad$ Catananche caerulea L.

78 Centaurea boissieri DC.

79 Centaurea calcitrapa L.

80 Centaurea diluta Aiton

(incl. C. elongata Schousb.)

81 Centaurea eriophora L.

82 Centaurea melitensis L.

83 Centaurea nana Desf.

84 Centaurea pullata $\mathrm{L}$.

$85 \quad$ Centaurea sphaerocephala $\mathrm{L}$.

86 Centaurea sulphurea Willd.

87 Chondrilla juncea $\mathrm{L}$.

88 Cichorium pumilum Jacq.

89 Cirsium echinatum (Desf.) DC.

90 Cirsium vulgare (Savi) Ten.

(incl. C. lanceolatum (L.) Scop.)

91 Cynara baetica (Spreng.) Pau subsp. maroccana Wiklund

92* Cynara scolymus L.

93 Dittrichia graveolens (L.) Greuter

94 Dittrichia viscosa (L.) Greuter

95 Echinops spinosissimus Turra

(incl. E. spinosus L.)

96 Erigeron bonariensis L.

97 Evacidium discolor (DC.) Maire

$98 \quad$ Filago pygmaea $\mathrm{L}$.

99 Filago pyramidata L

100 Galactites tomentosus Moench

101 Glebionis coronaria (L.) Spach

102 Hedypnois rhagadioloides (L.) F.W. Schmidt (incl. H. cretica (L.) Dum. Cours.)

103* Helianthus annuus L.

104* Helianthus tuberosus L.

105 Helminthotheca echioides (L.) Holub

106 Hypochaeris radicata $\mathrm{L}$. (incl. H. atlantica Sennen \& Mauricio)

107 Jacobaea gigantea (Desf.) Pelser

108 Jurinea humilis (Desf.) DC.

109 Lactuca saligna L.

110* Lactuca sativa L.

111 Lactuca serriola L. incl. L. scariola L.

112 Lactuca tenerrima Pourr.

113 Launaea fragilis (Asso) Pau (incl. L. resedifolia auct. Afr. N.) ouchen-taddela

ghijghij

ghijghij

assennan

assennan

tit tfounast

ikhef n-skour

tit tfounast

aâban ifigher

assennan

chouch mghil, assennan amellal

assennan

\#

assennan

\#

assennan

assennan

assennan

tighmas n-oulli

tizodia

assennan

assennan

tifghit

kherchef

tirrehla

tirrehla

taskra

tirrehla

\#

techroun

asselghagh izman, âalk

\#

ghadou mlal

aicha

tebbaâ chems, baïaâ chems

btata qasbia

\#

\#

touya n-oughi

\#

tifaf

khos

tifaf n-sem

tifaf

tighmas n-oulli 
Local name (s)

114 Launaea lanifera $\mathrm{Pau}$ (incl. L. spinosa subsp. acanthoclada Maire)

115 Launaea nudicaulis (L.) Hook. f.

116 Leontodon saxatilis Lam.

(incl. L. taraxacoides auct. Afr. N.)

117 Limbarda crithmoides (L.) Dumort.

118 Mantisalca salmantica (L.) Briq. \& Cavill.

119 Micropus supinus L.

120 Onopordum acaulon $\mathrm{L}$.

121 Onopordum macracanthum Schousb.

122 Picnomon acarna (L.) Cass.

123 Picris hispanica (Willd.) P.D. Sell

124 Podospermum laciniatum (L.) DC.

125 Ptilostemon dyricola (Maire) Greuter

126 Pulicaria arabica (L.) Cass.

127 Rhagadiolus stellatus (L.) Gaertn.

128 Rhaponticum acaule (L.) DC.

129 Santolina africana Jord. \& Fourr.

130 Scolymus hispanicus L.

131 Scolymys maculatus L.

132 Scorzonera caespitosa Pomel

(incl. S. pseudopygmaea Lipsch., incl. S. pygmaea auct. Afr. N.)

140 Taraxacum sp.

141 Tragopogon porrifolius L.

142 Urospermum picroides (L.) Scop. ex F.W. Schmidt

143 Xanthium spinosum L.

144 Xanthium strumarium L.

(incl. X. brasilicum Vell.)

145 Xeranthemum inapertum (L.) Mill.

Berberidaceae

146 Berberis hispanica Boiss. \& Reuter

Boraginaceae

147 Anchusa italica Retz.

148 Borago officinalis L.

149 Echium flavum Desf.

150 Echium humile Desf. subsp. pycnanthum (Pomel)

Greuter \& Burdet

151 Echium plantagineum L.

152 Lappula barbata (M. Bieb.) Gürke

153 Neatostema apulum (L.) I. M. Johnst.

Brassicaceae

154 Alyssum alyssoides (L.) L.

155 Alyssum atlanticum Desf.

156 Alyssum serpyllifolium Desf.

157* Brassica oleracea L.

158* Brassica oleracea L. var botrytis

tighmas n-oulli, tifsit

tighmas n-oulli

tizodia

tirrehla

tazemourt

\#

ifris

ifris

assennan amellal

tachefaiit

talma

\#

\#

becher n-yazad

tifeghouine

tayrart

taghediwt

taghediwt

tighmas n-oulli

talma

touya n-oughi

abeâou ntifyout

tifaf

tifaf

\#

iwjdam

tachiria

alamen, aliam ouyiis

babghoro

assennan

mzzer izm

\#

irghis

illes oufounas

illes oufounas

\#

\#

illes oufounas

lhenni imisawn

\#

\#

\#

\#

azegzaw

chiflor 
159* Brassica oleracea L. var capitata

kronb

160* Brassica rapa $\mathrm{L}$.

161 Capparis spinosa $\mathrm{L}$.

162 Capsella bursa-pastoris (L.) Medik.

163 Descurainia sophia (L.) Webb ex. Prantl

164 Eruca vesicaria (L.) Cav. subsp. sativa (Mill.) Thell.

165 Erysimum grandiflorum Desf.

166 Erysimum incanum Kunze

167 Erysimum sp.

168 Hirschfeldia incana (L.) Lagr.-Foss.

169 Hormatophylla spinosa (L.) Kupfer

170 Hornungia petraea (L.) Rchb.

171 Isatis tinctoria $\mathrm{L}$.

172 Lepidium draba L.

173 Lobularia maritima (L.) Desv.

174 Matthiola fruticulosa (Lœfl. ex L.) Maire

175 Moricandia arvensis (L.) DC.

176 Neslia apiculata Fisch., C. A. Mey. \& Avé- Lall.

177* Raphanus sativus L.

178 Rhaphanus raphanistrum $\mathrm{L}$.

179 Rorippa africana (Br.-B1.) Maire

180 Rorippa nasturtium-aquaticum (L.) Hayek (incl. Nasturtium officinale $\mathrm{R}$. Br.)

181 Sinapis alba $\mathrm{L}$.

182 Sinapis arvensis L.

183 Sisymbrium irio L.

184 Sisymbrium runcinatum Lag. ex. DC.

185 Vella pseudocytisus L.

Buxaceae

186 Buxus balearica Lam.

Cactaceae

187* Opuntia maxima Mill.

\section{Campanulaceae}

188 Campanula filicaulis Durieu

189 Trachelium caeruleum L.

Cannabaceae

190 Celtis australis L. Caprifoliaceae

191 Lonicera pyrenaica $\mathrm{L}$.

Caryophyllaceae

192 Arenaria armerina Bory

193 Bufonia mauritanica Murb.

194 Cerastium brachypetalum Desportes ex. Pers.

195 Cerastium gibraltaricum Boiss.

196 Dianthus sylvestris Wulfen

197 Gymnocarpos sclerocephalus (Decne.) Ahlgren \& Thulin

198 Herniaria cinerea DC.

199 Herniaria glabra L.

200 Herniaria pujosii Sauvage \& Vindt

201 Minuartia hamata (Hausskn. \& Bornm.) Mattf. incl. Queria hispanica L.)

202 Paronychia argentea Lam.

203 Silene vulgaris (Moench) Garcke

204 Vaccaria hispanica (Mill.) Rauschert (incl. V. pyramidata Medik.)

deft, left

taylolout

lâihiyane

oud doukhan

harfi

\#

\#

\#

\#

ifssi

\#

lachren

\#

âdes oujdad tachgarga

\#

\#

fjel

bouhamou labiad

bouâffar

aguernouj

bouhamou

bouhamou

bouhamou

harfi aouragh, lâihiyane

aznou, qazdir

baqs

tazart roumian, hendia

\#

\#

teghzaz

\#

\#

\#

\#

\#

\#

\#

herres lehjer

herres lehjer

\#

\#

tasettaiit

tighighit

wawghiyi 
N. Species

Cistaceae

205 Cistus creticus L.

206 Cistus laurifolius L.

207 Cistus salviifolius L.

208 Helianthemum cinereum (Cav.) Pers.

209 Helianthemum croceum (Desf.) Pers.

210 Helianthemum pergamaceum Pomel

211 Tuberaria lignosa (Sweet) Samp.

(incl. Helianthemum tuberaria (L.) Mill.)

Convolvulaceae (incl. Cuscutaceae)

212 Convolvulus arvensis L.

213 Convolvulus lineatus L.

214 Cuscuta epithymum (L.) L.

215 Cuscuta planiflora Ten.

216* Ipomoea batatas (L.) Lam.

Crassulaceae

217 Sedum sp.

Cucurbitaceae

218* Citrullus lanatus (Thunb.) Matsum. \& Nakai

219* Cucumis melo L.

220* Cucumis sativus L.

221* Cucurbita maxima $\mathrm{L}$.

222* Cucurbita pepo L.

223* Lagenaria leucantha var. longissima

Cupressaceae

224* Cupressus sempervirens L.

225 Juniperus oxycedrus L.

226 Juniperus phoenicea L.

227 Juniperus thurifera $\mathrm{L}$.

228 Tetraclinis articulata (Vahl) Mast.

Cynomoriaceae

229 Cynomorium coccineum $\mathrm{L}$.

Cyperaceae

230 Bolboschoenus glaucus (Lam.) S. G. Sm. (incl. Scirpus maritimus auct. Afr. N.)

231 Carex halleriana Asso

232 Cyperus fuscus L.

Dipsacaceae

233 Lomelosia stellata (L.) Raf.

Ephedraceae

234 Ephedra major Host.

Equisetaceae

235 Equisetum ramosissimum Desf.

Ericaceae

236 Arbutus unedo L.

Euphorbiaceae

237 Euphorbia chamaesyce L.

238 Euphorbia helioscopia L.

239 Euphorbia hirsuta L.

(incl. E.pubescens Vahl)

240 Euphorbia nicaeensis All.

Fabaceae

241 Astragalus alopecuroides L.

242 Astragalus armatus Willd.

Local name (s)

\author{
innaqrouch \\ ouchtobou \\ innaqrouch \\ ighes n-terfas \\ ighes n-terfas \\ aïchout \\ ighes n-terfas
}

asser-remram

louwaya

achekous n-temghart

achekous n-temghart

btata hlouwa

tifednine n-temghart

dellah

bettikh

khiar

takhssait

takhssait

slawi

aârâar roumi

taqa

aârâar

awal, tawalt

aârâar, aârâar lhor

hemzellou

azlaf

\#

azlaf

\#

tiziad

\#

sasnou

tinougha, tineqout tinougha, tineqout \#

tinougha, tineqout

\#

assennan oufounas 
Local name (s)

243 Astragalus bourgaeanus Coss.

tinifine oujdad

244 Astragalus caprinus L.

ibawn ighatan

245 Astragalus granatensis Lam.

tighardemt

(incl. A. boissieri Fisch.)

246 Astragalus hamosus L.

247 Astragalus sesameus L.

248* Cicer arietinum L.

249 Coronilla repanda (Poir.) Guss.

250 Coronilla scorpioides (L.) W. D. J. Koch

251 Cytisus balansae (Boiss.) Ball

252 Erinacea anthyllis Link

253 Genista quadriflora Munby

254 Hedysarum coronarium L.

255 Hippocrepis monticola Lassen (incl. H. scabra DC.)

256 Hippocrepis neglecta Lassen

257* Lens culinaris Medik.

258 Lotus arenarius Brot.

259 Medicago doliata Carmign.

260 Medicago minima (L.) L.

261 Medicago orbicularis (L.) Bartal.

262 Medicago polymorpha $\mathrm{L}$.

263* Medicago sativa $\mathrm{L}$.

264 Medicago suffruticosa DC.

265 Medicago truncatula Gaertn.

266 Melilotus indicus (L.) All.

267 Melilotus sulcatus Desf.

268 Onobrychis humilis (L.) G. Lopez

269 Ononis hispida Desf.

270 Ononis pseudoserotina Batt. \& Pit.

271 Ononis spinosa L.

272 Ononis thomsonii Oliv.

273* Phaseolus vulgaris L.

274* Pisum sativum L.

275 Scorpiurus muricatus L.

276 Scorpiurus vermiculatus L.

277 Trifolium isthmocarpum Brot.

278 Trifolium resupinatum $\mathrm{L}$.

279* Trigonella foenum-graecum L.

280 Trigonella monspeliaca L.

281 Trigonella polyceratia L.

282* Vicia faba L.

283 Vicia lutea L.

284 Vicia monantha Retz.

285* Vicia sativa $\mathrm{L}$.

Fagaceae

286 Quercus coccifera $\mathrm{L}$.

287 Quercus faginea Lam.

288 Quercus rotundifolia Lam. Gentianaceae

289 Centaurium pulchellum (Sw.) Druce

ibawn lekhla

tinifine oujdad

hammes

\#

ibawn lekhla

bourssoud

bounehar

ilouki

\#

\#

\#

âdes

becher n-yazad

fessa

fessa oujdad

fessa

fessa

fessa

fessa oujdad

fessa oujdad

wawbhir

wawbhir, fessa dighardaïn

saboun immissawn

akchoud

henna

bouqsib

akchoud, asghar

loubia

jelbana, tinifine

tamazought n-tighsi

tamazought n-tighsi

fessa oughioul

fessa oughioul

helba

fessa

fessa

ibawn

kersenna

tinifine, tinifine ifigher

tinifine, kersenna

akerrouch ilef

tachta

kerrouch

\#

tisennaf n-temghart

tisennaf n-temghart 
N. Species

292 Erodium moschatum (L.) L’Hér. Grossulariaceae

293 Ribes uva-crispa L. Heliotropiaceae

294 Heliotropium europaeum L. Hyacinthaceae

295 Drimia maritima (L.) Stearn

296 Muscari comosum (L.) Mill.

297 Ornithogalum narbonense L.

Iridaceae

298 Gladiolus italicus Mill. (incl. G. segetum Ker-Gawl.) Juglandaceae

299* Juglans regia L. Juncaceae

300 Juncus acutus L.

301 Juncus inflexus L.

302 Juncus maritimus Lam. Juncaginaceae

303 Triglochin palustris L. Lamiaceae

304 Ajuga chamaepitys (L.) Schreb.

305 Ajugaiva (L.) Schreb.

306 Lamium amplexicaule L.

307* Lavandula angustifolia Mill.

308 Lavandula stoechas L.

309 Marrubium alysson L.

310 Marrubium vulgare L.

311 Mentha longifolia (L.) L.

312 Mentha pulegium $\mathrm{L}$.

313* Mentha spicata L. (incl. M. viridis (L.) L.)

314 Mentha suaveolens Ehrh. (incl. M. rotundifolia auct. Afr. N.)

315* Mentha x piperita L.

316 Nepeta nepetella L. subsp. amethystina (Poir.) Briq.

317* Ocimum basilicum $\mathrm{L}$.

318 Origanum elongatum (Bonnet) Emb. \& Maire

319 Rosmarinus officinalis L.

320 Salvia argentea $\mathrm{L}$.

321 Salvia officinalis L.

322 Salvia phlomoides Asso

323 Salvia verbenaca $\mathrm{L}$.

324 Sideritis hirsuta L.

325 Teucrium chamaedrys L.

326 Teucrium fruticans $\mathrm{L}$.

327 Teucrium polium $\mathrm{L}$.

328 Thymus algeriensis Boiss. \& Reut.

329 Thymus munbyanus Boiss. \& Reut.

330 Thymus zygis L.

331 Ziziphora hispanica $\mathrm{L}$.

Liliaceae

332 Tulipa sylvestris L. Lythraceae
Local name (s)

tisennaf n-temghart

qars moumou

\#

bsel-ilef, bsel lhellouf

bsel n-iqzine

bsel n-iqzine

tafrout $n$-ouchen

guergaâ

azlaf

azlaf

azlaf

\#

timchouzzatine

timchouzzatine

naânaâ lma

khzama

ahelhal

timersat

timersate timerriwine

timersat

flyou dial lma, flyou ifounasen

naânaâ, liqama

timersat n-waman

naânaâ meskaoui

timersat tibouriyine

hbaq

istahdar, saâter

azir

aferghous n'ariou

belghabou, belghanbou

if tfounast

tiltit n-tmessi, lâarf n-yazad

menta

\#

azzou

tayrart, tayrirt

marad

zouchen

zouchen

flyou abouri 
N. Species

333 Lythrum junceum Banks \& Sol.

334* Punica granatum L. Malvaceae

335* Abelmoschus esculentus (L.) Moench

336 Althaea longiflora Boiss. \& Reut.

337 Hibiscus trionum L.

338 Malva neglecta Wallr.

339 Malva parviflora L. Molluginaceae

340 Corrigiola telephiifolia Pourr. Moraceae

341* Ficus carica L.

342* Morus alba L.

343* Morus nigra L. Nitrariaceae

344 Peganum harmala L. Oleaceae

$345 \quad$ Fraxinus angustifolia Vahl

346 Fraxinus dimorpha Coss. \& Durieu (incl. F.xanthoxyloides auct. Afr. N.)

347* Olea europaea L. subsp. europaea

348 Phillyrea angustifolia L.

Onagraceae

349 Epilobium hirsutum L. Orobanchaceae

350 Orobanche crenata Forssk. Papaveraceae

$351 \quad$ Fumaria agraria Lag.

352 Fumaria parviflora Lam.

353 Glaucium corniculatum (L.) H. Rudolph

354 Hypecoum pendulum L.

355 Papaver rhoeas $\mathrm{L}$.

356 Roemeria hybrida (L.) DC. Pinaceae

357 Cedrus atlantica (Endl.) Carrière

358 Pinus halepensis Mill.

359 Pinus pinaster Aiton Plantaginaceae

360 Antirrhinum majus L.

361 Chaenorrhinum villosum (L.) Lange

362 Globularia alypum L.

363 Globularia nainii Batt.

364 Plantago albicans L.

365 Plantago coronopus L.

366 Plantago major L.

367 Plantago mauritanica Boiss. \& Reut.

368 Plantago rhizoxylon Emb.

369 Veronica anagallis-aquatica L.

$370 \quad$ Veronica rosea Desf.

Poaceae

371 Aegilops geniculata Roth

372 Aegilops triuncialis L.

373 Agrostis gigantea Roth

374 Alopecurus arundinaceus Poir.
Local name (s)

\#

romman

mloukhia

tibbi

\#

tibbi

tibbi

tawsarghint

tazart

tout labiad

tout lekhal

harmel

aderdar

touzzelt

azemour, zitoun

inouktal

\#

hemzellou

tifsit n-oujdad, chiba tifsit n-oujdad, chiba benaâmam ifigher tabellaâmant dighardain benaâmam tabellaâmant

idil

tayda

tayda

\#

\#

tasselgha

siwrigh

almzeimer

messassa, talamine

messassa

\#

\#

aguernouj

\#

harziz

harziz

\#

\# 
N. Species

375 Ampelodesmos mauritanicus (Poir.) Dur. \& Schinz

376 Anisantha madritensis (L.) Nevski

377 Anisantha rigida (Roth) Hyl.

378 Anisantha rubens (L.) Nevski

379 Anisantha tectorum (L.) Nevski

380 Anthoxanthum odoratum $\mathrm{L}$.

381 Arundo donax L.

382* Avena sativa $\mathrm{L}$.

383 Avena sterilis L.

384 Brachypodium retusum (Pers.) P. Beauv.

385 Bromus hordeaceus L.

386 Ctenopsis pectinella (Delile) De Not.

387 Cynodon dactylon (L.) Pers.

388 Dactylis glomerata L.

389 Dasypyrum breviaristatum (H. Lindb.) Fred.

(incl. D. hordeaceum (Coss. \& Dur.) P. Candargy)

390 Digitaria sanguinalis (L.) Scop.

391 Echinaria capitata (L.) Desf.

392 Echinochloa colona (L.) Link

393 Elytrigia repens (L.) Desv. ex Nevski

394 Eragrostis sp.

395 Hordeum murinum L.

396* Hordeum vulgare L.

$397 \quad$ Koeleria splendens C. Presl

398 Lolium multiflorum Lam.

399 Lolium rigidum Gaud.

$400 \quad$ Lygeum spartum L.

401 Macrochloa arenaria (Brot.) Kunth

402 Macrochloa tenacissima (L.) Kunth

403 Melica cupanii Guss.

404 Paspalum distichum $\mathrm{L}$.

405 Phalaris minor Retz.

406 Phragmites australis (Cav.) Steud. (incl. Ph. communis Trin.)

407 Polypogon monspeliensis (L.) Desf.

408 Schedonorus arundinaceus (Shreb.) Dumort.

409 Schismus barbatus (Lœfl. ex L.) Thell.

410* Secale cereale $\mathrm{L}$.

411 Setaria verticillata (L.) P. Beauv.

412* Sorghum bicolor (L.) Mœnch

413 Sorghum halepense (L.) Pers.

414 Stipa lagascae Roem. \& Schult.

415 Trachynia distachya (L.) Link

416* Triticum aestivum L.

417* Triticum durum Desf.

418* Zea mays L.

Polygonaceae

419 Emex spinosa (L.) Campd.

420 Polygonum aviculare L.

421 Rumex bucephalophorus L.

422 Rumex conglomeratus Murray

423 Rumex crispus L.

424 Rumex pulcher L.

425 Rumex roseus $\mathrm{L}$.

Portulacaceae
Local name (s)

adles

bahma

bahma

bahma

bahma

ajdir tbadart

aghanim, ghanim

tamensikht

tamensikht

oubbal

oubbal saguia

\#

njem

tachaboubt

\#

\#

tiçennanine ou-mouch

\#

njem

\#

taghardait

tomzine

aghesmir

taghesmirt, medhouna

taghesmirt, medhouna

tasennaght

tadaft

ary, algdim

\#

\#

acheboub

tnala, ghanim, aghanim

\#

\#

\#

tasehdit

memâach

abaâli

tatkhant

anezd ou-winnouz

taghardait

farina

irden

dra

tasemount

asseremram

tasemount

\#

imejan aghioul, tasemount

tasemount

\# 
426 Portulaca oleracea L. timeqsine, rejla Primulaceae

427 Androsace maxima L.

428 Coris monspeliensis L.

\#

429 Lysimachia arvensis (L.) U. Manns \& Anderb.

alellou

430 Lysimachia fomina (Mill.) U. Manns \& Anderb.

alellou

Ranunculaceae

431 Adonis aestivalis L.

tit n-teskourt

432 Adonis microcarpa DC.

433 Consolida orientalis (J. Gay) Schrodinger

434 Delphinium obcordatum DC.

435 Ranunculus arvensis L.

436 Ranunculus trilobus Desf.

Resedaceae

437 Reseda alba L.

438 Reseda lanceolata Lag.

439 Reseda lutea $\mathrm{L}$

440 Reseda luteola $\mathrm{L}$.

441 Reseda phyteuma $\mathrm{L}$.

Rhamnaceae

442 Rhamnus alaternus L.

tit n-teskourt

azbibi

\#

fetchras

touya n-bouzelloum

tajellalt izimer, ajellal n-tghat

tajellalt izimer

tajellalt izimer

tajellalt izimer

tajellalt izimer

amliles

Rosaceae

443 Amelanchier ovalis Medik.

tazart imisawn

ameqsou

admam

admam

sferjel

mzah

fraize

teffah

tiliban taria

mechmach

hab lemlouk

hab lemlouk

berqouq

louz

khoukh

aberqouq imisawn

tfirast, bouaouid

tabgha

ward beldi

tatchelt

touya n-ifigher

menned

menned

menned

menned

menned

fetchras

taroubia

471 Ruta montana (L.) L. iwermi

Salicaceae 
472 Populus alba L.

473 Populus nigra $\mathrm{L}$.

474 Salix alba $\mathrm{L}$.

475 Salix atrocinerea Brot.

476 Salix babylonica L.

477 Salix purpurea L.

Santalaceae

478 Viscum cruciatum Boiss.

Scrophulariaceae

479 Scrophularia auriculata L.

480 Scrophularia canina L.

481 Scrophularia macrorrhyncha (Humbert, Litard. \& Maire) Ibn Tattou

482 Verbascum dentifolium Delile

Smilacaceae

483 Smilax aspera L.

Solanaceae

484 Atropa belladonna L.

485 Capsicum annuum $\mathrm{L}$.

486 Datura stramonium L.

487 Hyoscyamus albus L.

488 Hyoscyamus niger $\mathrm{L}$.

489 Lycium europaeum L.

490* Lycopersicum esculentum Mill.

491 Solanum melongena L.

492 Solanum nigrum L.

493* Solanum tuberosum L.

Tamaricaceae

494 Tamarix aphylla (L.) H. Karst.

495 Tamarix canariensis Willd.

Taxaceae

496 Taxus baccata $\mathrm{L}$.

Thymelaeaceae

497 Daphne gnidum L.

498 Daphne laureola L.

499 Thymelaea tartonraira (L.) All.

500 Thymelaea virgata (Desf.) Endl.

Tuberaceae

501 Terfzia $\mathrm{sp.}$

502 Tirmania sp.

Typhaceae

503 Typha angustifolia L.

Urticaceae

504 Urtica urens L.

Verbenaceae

505* Aloysia citrodora Palau

506 Verbena officinalis L.

Vitaceae

507 Vitis vinifera L.

Zygophyllaceae

508* Balanites aegyptiaca (L.) Delile asefsaf

asefsaf

afssas, tafssaft

afssas roumi

swalef aïcha

afssas

mejbar

saboun taria, saboun naria

chtaba, ilzwine

chtaba, ilzwine

aferghous n-ariou

anesfal, tanesfalt

chaoulou, adil n-ouchen

ifelfel

taborzizt

inyad

guinguet

âwej, âadlouj

maticha

denjal

adil n-ouchen

btata

hadba

tamimaït

dakhch

alzaz

\#

talzazt

tasra

tirfas tizougaghine

tirfas timellaline

tabouda

tiqzinine, taqzinte

louiza

\#

adil

tmar-tork, tmar lkhaoui 